\title{
Identification of novel TDRD7 isoforms
}

\author{
O. M. Skorokhod, D. O. Gudkova, V. V. Filonenko
}

State key laboratory of molecular and cellular biology

Institute of Molecular Biology and Genetics, NAS of Ukraine

150, Akademika Zabolotnoho Str., Kyiv, Ukraine, 03680

filonenko@imbg.org.ua

\begin{abstract}
Aim. The aim of our study was to investigate the tudor domain-containing protein 7 (TDRD7) subcellular localization, which could be linked to diverse functions of this protein within the cell. Methods. In this study we employed cell imaging technique for detecting TDRD7 subcellular localization, Western blot analysis of HEK293 cell fractions with anti-TDRD7 monoclonal antibodies and bioinformatical search of possible TDRD7 isoforms in Uniprot, Ensemble, UCSC databases. Results. We have observed specific TDRD7-containing structures in cytoplasm as well as in the nucleus in HEK293 cells. The Western blot analysis of subcellular fractions (cytoplasm, mitochondria, nucleus) allowed us to detect three lower immunoreactive bands, with the

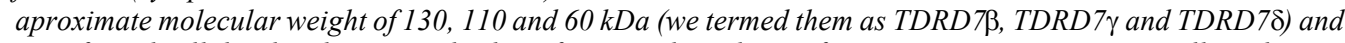
specific subcellular localization. The bioinformatical analysis of TDRD7 primary structure allowed us to determine two alternative transcripts from TDRD7 gene coding for proteins with calculated molecular weight of 130 and $60 \mathrm{kDa}$. Conclusion. The presented data demonstrate the existence at protein level of potential TDRD7 isoforms: TDRD7 $\beta, T D R D 7 \gamma$ and TDRD78. The expression profile of these splice variants and their role in cells remains to be elucidated.
\end{abstract}

Keywords: TDRD7, S6 kinase, isoform, piRNAs, translation.

Introduction. Cell growth is a complex and at the same time tightly coordinated process. It requires the presence of different stimulatory molecules and sufficient quantities of nutrients, an appropriate work of translational apparatus and consistent cytoskeleton dynamics [1]. The key regulators of cell growth are mTOR and ribosomal protein S6 kinases (S6Ks), involved in the PI3K-mTOR signaling pathway. The activity of S6Ks and mTOR is regulated by phosphorylation/dephosphorylation events and requires different protein-protein interactions either with up-stream effectors or with specific substrates, which are facilitated/regulated by scaffold proteins [2].

One of a such possible regulators is TDRD7 (tudor domain containing 7) protein, referred also as PCTAIRE2BP (PCTAIRE2 binding protein) or Trap (tudor

(C) Institute of Molecular Biology and Genetics, NAS of Ukraine, 2011 repeat associator with PCTAIRE 2) or KIAA1529. Recently it was identified by yeast two-hybrid system as a S6K1-binding partner [3]. TDRD7 is a scaffold protein with molecular weight of about $130 \mathrm{kDa}(160 \mathrm{kDa}$ in SDS-PA-GE), first detected in a complex of Ser/Thr PCTAIRE2 kinase [4]. TDRD7 was found to associate with proteins which regulate microtubule dynamics, mRNA transport and protein translation apparatus, and thus could indirectly affect the mTOR/S6K signaling pathway. It is a member of the tudor domains containing proteins group, highly enriched in germ cells and involved in the formation of polar/germinal granules (or nuage), the electron-dense organelles, abundant in RNA and proteins, crucial for spermatogenesis and some of small RNA pathways in the germline of many organisms $[5,6]$.

In human cells TDRD7 is predominantly expressed in brain and testis [4]. The TDRD7 gene is conserved in 
chimpanzee, dog, cow, mouse, rat, chicken, and zebrafish. The gene consists of 18 exons and its nucleotide sequence in human displays 80-99\% identity with Mus musculus, Rattus norvegicus, Canis familiaris, Pan troglodytes (www.genecards.org). It has been reported recently that human TDRD7 mutations result in the cataract formation via misregulation of specific developmentally critical lens transcripts, and the TDRD7 null mutant mice develop cataract as well as glaucoma, the latter defined by elevated intraocular pressure (IOP) and optic nerve damage [7].

It was shown that in HeLa, COS7 cells TDRD7 is observed in the cytoplasm: it may localize on the periphery of mitochondria through electrostatic interaction and together with some other members of tudor-family (TDRD1/MTR-1, TDRD6) specifically localized in nuage (chromatoid body), which contains Dicer and microRNAs, suggesting that this structure is involved in a microRNA pathway and form a ribonucleoprotein complex in spermatids [4, 8-10]. It was also reported that after overexpression of TDRD7 in COS7 cells a small portion of this protein was detected in nucleus [11].

According to the recent data, in cytoplasm TDRD7 is involved in complexes with ik3/Cables, a cyclin-dependent kinase binding protein, and with TACC1chTOG-Aurora kinase A, which could control mRNA movement depending on microtubule organization in the establishment or maintenance of cell polarity [11-13].

An essential feature of TDRD7 is the presence of Tudor repeats, which form a conserved 60 -amino acid large domain, initially described in proteins associated with nucleic acids [14-16]. The structural analysis of the Tudor fold reveals a barrel-like structure composed of $\beta$-sheets forming a hydrophobic pocket surrounded by negatively charged residues that more likely constitute a protein-protein interaction surface $[14,17]$. It has been established recently, that Tudor domains are specialized in specific recognition of methylated lysine or methylated arginine residues, and are involved in various epigenetic functions, such as chromatin remodeling through histones demethylation, and RNA processing via regulation mRNA splicing machinery and RISC activity [14, 18-20]. Moreover, it is suggested that a possible function of Tudor domain repeats in proteins, which carry out several such motives in their structure, is to act like chaperones and assemble molecules that as- sociate with each Tudor domain into macromolecular complexes [8, 21].

The bioinformatical studies performed recently allowed identification and description of new domains in the N-terminal region of TDRD7, named LOTUS (Limkain, Oskar and Tudor containing proteins 5 and 7) [22]. TDRD7 has three such domains: LOTUS 1 (1115 aa), LOTUS 2 (160-315 aa) and LOTUS 3 (335420 aa). LOTUS domains are non-conserved (17-30\% homology) globular structures found in various proteins from metazoans and plants. They are often associated with RNA-specific modules and are likely to adopt a winged helix fold, but the exact molecular role of LOTUS domain remains to be discovered.

The involvement of TDRD7 in different cellular complexes and its role in specific classes of RNA transport, processing, translation regulation, microtubule organization, indicate the importance of TDRD7 functions in cell and the necessity of further investigation.

Recently, a potential link between the mTOR/S6K signaling pathway and TDRD7 has been established, as far as this protein has been found among S6K1 partners in yeast two-hybrid screen [3]. In this study, we present the data indicating the existence of potential novel TDRD7 isoforms termed TDRD7 $\beta$, TDRD7 $\gamma$ and TDRD7 $\delta$. All these forms are shorter than the main TDRD7 $\alpha(160 \mathrm{kDa})$ form and possess molecular weight of 130, 110 and $60 \mathrm{kDa}$ correspondingly.

We have observed a different subcellular localization of the TDRD7 variants by Western blot analysis of HEK293 cellular fractions. According to our data TDRD $7 \alpha$ and TDRD7 $\beta$ isoforms predominantly exis in cytosol, TDRD7 $\gamma$ in mitochondrial and TDRD7 $\delta$ in nuclear fractions respectively. These data are in agreement with the results of confocal study indicating the presence of TDRD7 not only in cytoplasm, but also in nucleus.

Materials and methods. Bioinformatics. A new TDRD7 splice variant was identified using Uniprot (www. uniprot.org) and Ensemble (www.ensembl.org) databases and ASAP program [23]. This web-tool is based on an automated method for discovering human tissue-specific regulation of alternative splicing through a genome-wide analysis of expressed sequence tags (ESTs) that involves classifying human EST libraries according to tissue categories and Bayesian statistical analysis. 
The BLAST analysis for 290-411 aa fragment (F2) of TDRD7 was performed using BLAST Network Service on ExPASy (http://web.expasy.org) and SCANPS (Similarity searches using Barton's algorithm - http:// www.ebi.ac.uk).

Western blot analysis. Cell lysate was prepared in a lysis buffer containing $20 \mathrm{mM}$ Tris- $\mathrm{HCl}, \mathrm{pH} 7.5$, $150 \mathrm{mM} \mathrm{NaCl}, 1 \%$ Triton X-100, $50 \mathrm{mM} \mathrm{NaF}, 1 \mathrm{mM}$ EDTA, and a mixture of protease inhibitors (Roche Molecular Diagnostics). A portion of total lysate $(40 \mu \mathrm{g})$ was separated by SDS-PAGE and immunoblotted with anti-TDRD7 antibodies as described previously [24]. Secondary HRP-labelled anti-mouse antibodies were from «Cell Signaling» (USA).

Cell culture and immunocytochemistry. HEK293 cells were obtained from the American Type Culture Collection and maintained in DMEM supplemented with $10 \%$ fetal bovine serum («HyClone», UK), penicillin $(200 \mathrm{U} / \mathrm{ml})$ and streptomycin $(200 \mathrm{mg} / \mathrm{ml})$. For immunofluorescent staining HEK293 cells were grown in tissue culture chambers («Nunc», Denmark), fixed with $3.7 \%$ formaldehyde in PBS, and permeabilized with PBS-T $(0.2 \%$ Tween-20) three times for $5 \mathrm{~min}$. Unspecific binding was blocked by $45 \mathrm{~min}$ incubation of cells with $5 \%$ FBS diluted in PBS-T. Afterwards staining with primary and secondary antisera was performed as described previously [25], anti-mouse Alexa-Fluor 546-conjugated secondary antibodies were from «Invitrogen» (USA). Fluorescently labelled proteins were visualized with a Zeiss LSM510 confocal microscope, and the images were analyzed using the LSM510 image browser software [26]. Nuclei were stained with Hoechst 33258 («Sigma», USA).

Isolation and preparation of cell fractions. Cell fractions were obtained using different centrifugation conditions according to the protocol [27]. Briefly, HEK 293 cells were washed with phosphate buffered saline two times. Cells were scraped in $400 \mu 1$ ice-cold IB-1 buffer $(225 \mathrm{mM}$ manitol, $75 \mathrm{mM}$ sucrose, $30 \mathrm{mM}$ Tris-HCl, $\mathrm{pH} 7,4$, and 0,1 mM EGTA), homogenized and then centrifuged at $600 \mathrm{~g}$ for $5 \mathrm{~min}$ at $4{ }^{\circ} \mathrm{C}$. The pellet, which contains nuclear fraction was freezed and stored at $-20^{\circ} \mathrm{C}$. Supernatant was collected and centrifuged at $7000 \mathrm{~g}$ for $10 \mathrm{~min}$ at $4{ }^{\circ} \mathrm{C}$. Supernatant was separated, freezed and stored at $-20{ }^{\circ} \mathrm{C}$. The pellet (containing mitochondrial fraction) was gently resus- pended with IB-2 buffer ( $225 \mathrm{mM}$ manitol, $75 \mathrm{mM}$ sucrose, $30 \mathrm{mM}$ Tris- $\mathrm{HCl}, \mathrm{pH} 7,4)$, frozen at $-20{ }^{\circ} \mathrm{C}$.

Results and discussion. Previous molecular cloning of TDRD7 fragments allowed us to develop specific monoclonal antibodies against this protein directed to 290-411 aa part of TDRD7 [23]. This fragment contains a part of LOTUS domain identified recently using the sequence profile analysis. BLAST Network Service on ExPASy and SCANPS for this amino acid sequence revealed the presence of this fragment exclusively in TDRD7 protein in human cells.

It has been already demonstrated that TDRD7 is localized on the mitochondria outer membrane and in cytoplasmic structures called chromatoid bodies $[5,6]$. We employed an immunofluorescent-confocal microscopy and anti-TDRD7 (E6) monoclonal antibody for more precise studying TDRD7 intracellular localization. The data of confocal studies (Fig. 1, see inset) indicate that a red fluorescent signal corresponding to TDRD7 was detected not only in the cytoplasm, but in the nucleus as well. Especially strong TDRD7 positive signal was observed in the perinuclear zone and in the region of mitotic spindle formation (marked with arrows). These data show that some fraction of endogenous TDRD7 is present in the nucleus of wild HEK293 cells, the fenomenon, which has been observed previously only for COS7 cells overexpressing TDRD7 [11].

To get an additional evidence supporting the TDRD7 nuclear localization we have performed a subcellular fractionation of HEK293 cells with subsequent Western blot analysis. Surprisingly, we have detected the presense of not only $160 \mathrm{kDa}$ TDRD7 protein band (TDRD7 $\alpha$ ), but also additional bands of about $130 \mathrm{kDa}$ (TDRD7 $\beta$ ) in cytosolic fraction. At the same time protein bands of $110 \mathrm{kDa}(\mathrm{TDRD} 7 \gamma)$ and $60 \mathrm{kDa}(\mathrm{TDRD} 7 \delta)$ recognized by TDRD7 mAbs were detected in mitochondrial and nuclear fractions (Fig. 2). These data indicate the existence of additional isoforms of TDRD7 named as TDRD7 $\beta$, TDRD7 $\gamma$ and TDRD7 $\delta$ correspondingly.

To analyse a possibility of TDRD7 isoforms existence we made an extensive bioinformatical analysis. The performed search confirmed the presence of only one gene coding for TDRD7 in the mammalian genome. However, the screening of UniProt and Ensemble databases led to the identification of two alternative TDRD7 transcripts (short and long) with open 


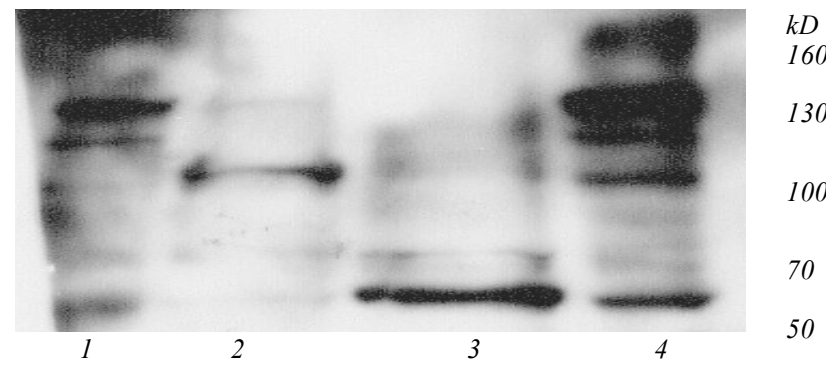

Fig 2. TDRD7 isoforms detected in different subcellular fractions of HEK 293 cells. HEK293 cells were lyzed and subcellular fractions were obtained using different centrifugation conditions and manitol according to the protocol [25]. All forms of TDRD7 are presented in total cell lysate; TDRD7 $\alpha(160 \mathrm{kDa})$ and TDRD7 $\beta(130 \mathrm{kDa})$ only in cytosolic fraction, while TDRD7 $\gamma(110 \mathrm{kDa})$ in mitochondrial and TDRD7 $\delta$ $(60 \mathrm{kDa})$ in nuclear fractions respectively 1 - cytoplasm; 2 - mitochondria; 3 - nucleus; 4 - total cell lysate
In UCSC database there are some TDRD7 EST clones corresponding to the protein, which contains N-terminal sequences and lacks the $\mathrm{C}$-terminal sequence of TDRD7. Hence, it is possible that the predicted TDRD7 $\delta$ is a product of specific C-terminal splicing of TDRD7 $\alpha$. However, additional studies should be performed to analyse either they represent just fragments of known TDRD7 $\alpha$ or novel isoforms of TDRD7.

Taking together, our results demonstrated the possible existence of novel isoforms of TDRD7 named TDRD7 $\beta$, TDRD7 $\gamma$ and TDRD7 $\delta$, which are characterized by different subcellular localization. But etc., an additional research, and first of all PCR analysis of cDNA from HEK293 cells, has to be performed to pro-
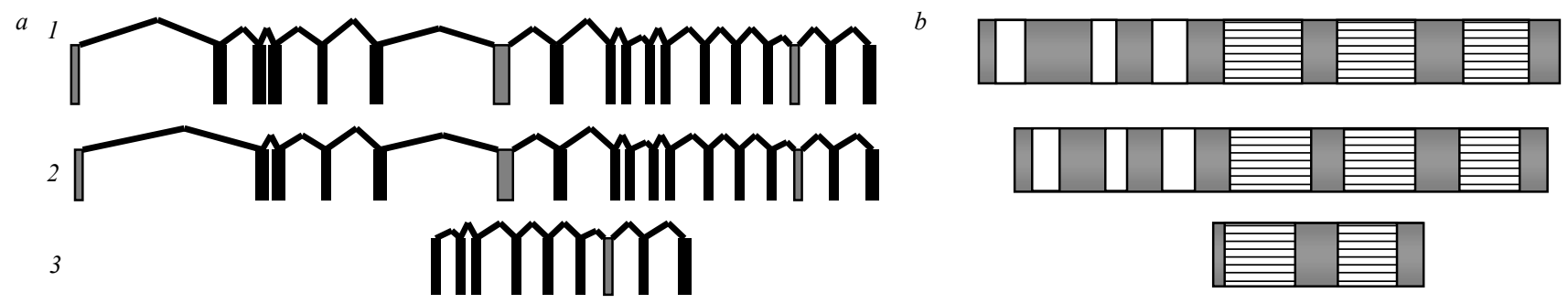

Fig. 3. Bioinformatic analysis indicates the existence of potential splicing isoforms of TDRD7 protein: $a-$ alternative transcripts of the human TDRD7 gene predicted by UniProt and Ensemble ( 1 - main form; 2 and 3 -splice variants). The existence of 2 potential splice variants of TDRD7 mRNAs is indicated ( 2 and 3 ). Introns are shown as lines and exons are shown as boxes; $b$ - schematic presentation of domain organization in splicing forms of TDRD7

reading frame coding for hypothetical 130 and $60 \mathrm{kDa}$ TDRD7 isoforms. The sequence analysis revealed the absence of exon 2 in the long transcript and several exons $(1-9,11)$ in the short one. Fig. $3, a$, shows the intron/exon boundary of known TDRD7 form (TDRD7 $\alpha$ ) and new splicing variants. The existence of possible TDRD7 alternative transcripts was further confirmed with ASAP program and UCSC database (http://geno me.ucsc.edu/).

Analysing the data received we may predict that TDRD7 $\beta$ detected by Western blot analysis represents $130 \mathrm{kDa}$ TDRD7 isoform expressed from the long alternative TDRD7 transcript revealed by bioinformatical search. The short alternative TDRD7 transcript (Fig. 3) coding for $60 \mathrm{kDa}$ protein represents different from TDRD7 $\delta$ isoform with similar molecular weight. The specific epitope for anti-TDRD7 mAbs (290- 411 aa) used in WB is absent in the short transcript protein product (Fig. 3). ve that the identified protein bands represent novel TDRD7 isoforms. Moreover, the screening of the TDRD7 isoforms in different cell lines and tissues at RNA and protein levels is necessary to determine the physiological importance of the new isoforms. The presence of N-terminal LOTUS domains which can bring TDRD7 into the complexes with RNA-protein modules could explain the appearence of TDRD7 $\delta$ isoform in perinuclear and nuclear zones. Using a panel of TDRD7 siRNAs or shRNAs it would be possible to get an additional evidence of novel TDRD7 isoform existence.

Conclusions. In summary, we have provided evidence for the existence of novel, most probably alternatively spliced isoforms of TDRD7, named TDRD7 $\beta$, TDRD7 $\gamma$ and TDRD7 8 . According to the confocal microscopy studies and Western blot analysis of subcellular fractions of HEK293 cells we have suggested the presense of TDRD7 $\beta$ isoform in cytoplasm (together 
Fig. 1 to article by Skorokhod O. M. et al.
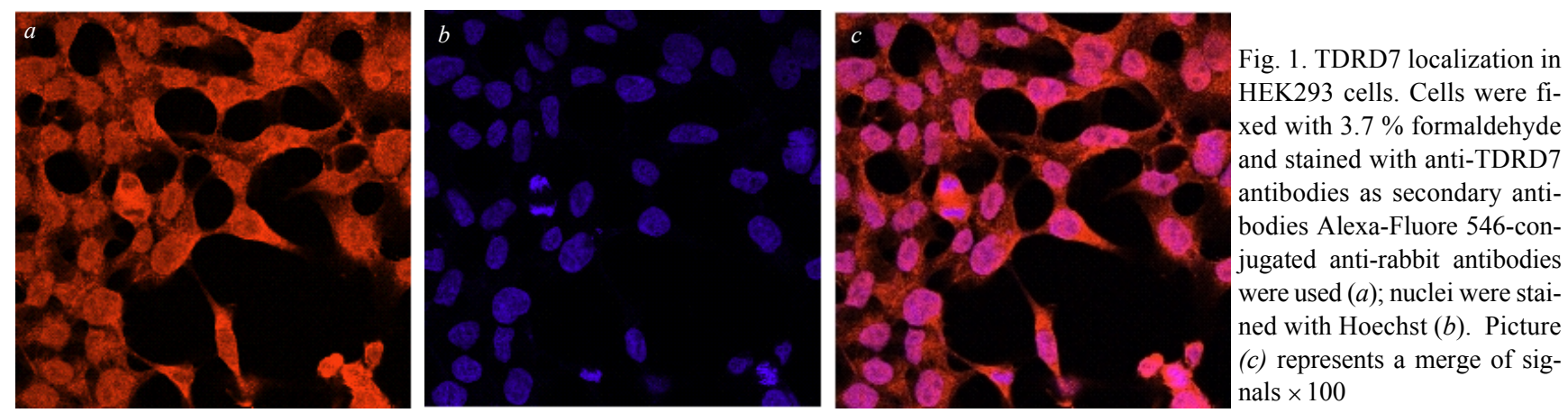

Fig. 6 to article by Mohylyak I. I. et al.
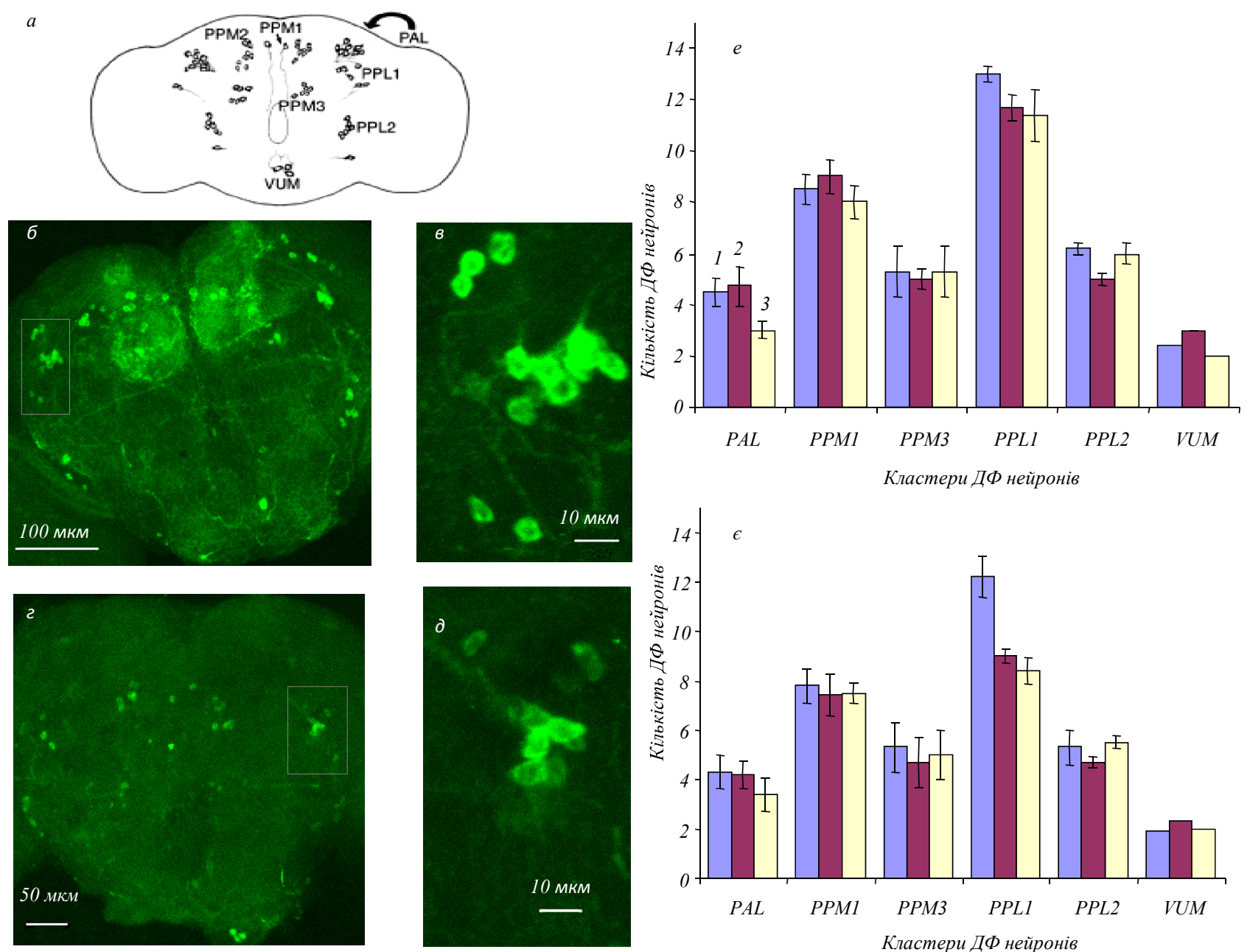

Рис. 6. Кластери дофамінергічних нейронів (ДФ) у мозку D. melanogaster: $a$ - схема розміщення кластерів ДФ нейронів у мозку: $P A L-$ protocerebral anterior lateral; $P P M$ - protocerebral posterior medial; $V U M$ - ventral unpaired medial; $P P L$ - protocerebral posterior lateral [26, 27]; $6-\partial-\mathrm{Z}$-проекція серії зображень тканини мозку 23-денних особин після імунологічної детекції антитілами anti-TH, одержаних на конфокальному мікроскопі ( $\sigma$ - дикий тип, $\times 20$; в-дикий тип, $\times 40 ; 2-$ мутант $72-7, \times 20 ; \partial$ - мутант 72-7, ×40); кількість ДФ нейронів основних кластерів головного мозку D. melanogaster: $e$ - триденних; $\epsilon-21$-денних особин (1-лінія Oregon; $2-$ sws $\left.^{o l f E} ; 3-76-15\right)$ 
with the canonical TDRD7 $\alpha$ form), TDRD7 $\gamma$ in mitochondrial and TDRD7 $\delta$ in nuclear fractions respectively. The expression profile of these splice variants and their role in cells remain to be elucidated.

Acknowledgements. The work was supported with grants from the National Academy of Sciences of Ukraine. We thank Dr. V. Gorchev and Dr. S. Karahim for help in confocal studies.

\section{О. М. Скороход, Д. О. Гудкова, В. В. Філоненко}

Виявлення нових ізоформ TDRD7

Державна ключова лабораторія молекулярної і клітинної біології Інститут молекулярної біології і генетики НАН України Вул. Академіка Заболотного, 150, Київ, Україна, 03680

\section{Резюме}

Мета. Мета досліджень полягала у вивченні внутрішньоклітинної локалізації TDRD7, що може бути пов'язано з різними функиіями даного білка в клітинах. Методи. Застосовано метод імуноцитохімї для детекції субклітинної локалізації TDRD7, вестерн-блот аналіз клітинних фракиій НЕК293 з використанням анти-TDRD7 моноклональних антитіл та біоінформатичний пошук можливих ізоформ TDRD7 у базах даних Uniprot, Ensemble, UCSC. Результати. Специфічні TDRD7-вмісні структури виявлено в иитоплазмі, а також у ядрах клітин НЕК293. Імуноблотаналізом субклітинних фракцій (цитоплазма, мітохондрії, ядро) детектовано три імунореактивні смуги з молекулярними масами

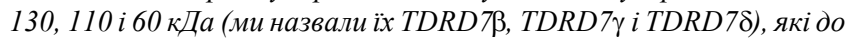
сьогодні не були охарактеризовані. Біоінформатичним аналізом первинної структури TDRD7 визначено два альтернативних транскрипти TDRD7-гена, продукти транслячії яких відповідають двом гіпотетичним ізоформам, ідентифікованим в імуноблоmi (TDRD7ß (130 кДа) ma TDRD78 (60 кДа)). Висновки. Отримані дані вказують на можливість існування потениійних ізо-

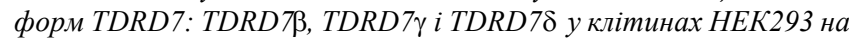
білковому рівні. 3'ясування особливостей експресії та ролі нових форм TDRD7 у клітинах потребує подальших досліджень.

Ключові слова: TDRD7, S6 кіназа, ізоформа, піРНК, трансляція.

\section{А. Н. Скороход, Д. О. Гудкова, В. В. Филоненко}

Идентификация новых изоформ TDRD7

\section{Резюме}

Цель. Цель исследования состояла в изучении внутриклеточной локализации TDRD7, что может быть связано с различными функииями данного белка в клетках. Методы. Применен метод иммуноцитохимии для детекции субклеточной локализации TDRD7, вестерн-блот анализ клеточных фракций НЕК293 с использовавнием анти-TDRD7 моноклональных антител и биоинформатический поиск возможных изоформ TDRD7 в базах данhblx Uniprot, Ensemble, UCSC. Результаты. Cпецифические TDRD7-содержащие структуры выявлены в циитоплазме, а также в ядрах клеток НЕК293. Иммуноблот-анализом субклеточных фракций (цитоплазма, митохондрии, ядро) определены три иммунореактивные полосы с молекулярными массами 130, 110 u

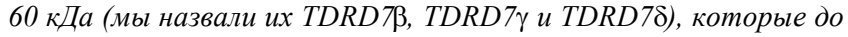

настоящего времени не были охарактеризованы. Биоинформатическим анализом первичной структуры TDRD7 детектированы два альтернативных транскрипта TDRD7-гена, продукты трансляции которых соответствуют двум гипотетическим изоформам, идентифицированным в иммуноблоте (TDRD7及 (130 кДа) и TDRD7反 (60 кДа)). Выводы. Полученные данные указывают на возможность существования потенциальных изоформ

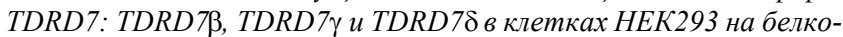
вом уровне. Выяснение особенностей экспрессии и роли новых форм TDRD7 в клетках требует дальнейших исследований.

Ключевые слова: TDRD7, S6 киназа, изоформа, пиРНК, трансляция

\section{REFERENCES}

1. Fingar D. C., Salama S., Tsou C., Harlow E., Blenis J. Mammalian cell size is controlled by mTOR and its downstream targets S6K1 and 4EBP1/eIF4E // Genes Dev.-2002.-16, N 12.P.1472-1487.

2. Inoki K., Ouyang H., Li Y., Guan K.-L. Signaling by target of rapamycin proteins in cell growth control // Microbiol. Mol. Biol. Rev.-2005.-69, N 1.-P. 79-100.

3. Panasyuk G., Nemazanyy I., Filonenko V., Zhyvoloup A. Largescale yeast transformation in low-percentage agarose medium // BioTechniques.-2004.-36, N 1.-P. 40-44.

4. Hirose T., Kawabuchi M., Tamaru T., Okumura N., Nagai K., Okada $M$. Identification of tudor repeat associator with PCTAIRE 2 (Trap). A novel protein that interacts with the N-terminal domain of PCTAIRE 2 in rat brain // Eur. J. Biochem.-2000.267, N 7.-P. 2113-2121.

5. Chuma S., Hosokawa M., Kitamura K., Kasai S., Fujioka M., Hiyoshi M., Takamune K., Noce T., Nakatsuji N. Tdrd1/Mtr-1, a tudor-related gene, is essential for male germ-cell differentiation and nuage/germinal granule formation in mice // Proc. Natl Acad. Sci. USA.-2006.-103, N 43.-P. 15894-15899.

6. Vasileva A., Tiedau D., Firooznia A., Muller-Reichert T., Jessberger $R$. Tdrd6 is required for spermiogenesis, chromatoid body architecture, and regulation of miRNA expression // Curr. Biol.-2009.-19, N 8.-P. 630-639.

7. Lachke S. A., Alkuraya F. S., Kneeland S. C., Ohn T., Aboukhalil A., Howell G. R., Saadi I., Cavallesco R., Yue Y., Tsai A. C., Nair K. S., Cosma M. I., Smith R. S., Hodges E., Alfadhli S. M., Al-Hajeri A., Shamseldin H. E., Behbehani A., Hannon G. J., Bulyk M. L., Drack A. V., Anderson P. J., John S. W., Maas R. L. Mutations in the RNA granule component TDRD7 cause cataract and glaucoma // Science.-2011.-331, N 6024.- P. 15711576.

8. Hosokawa M., Shoji M., Kitamura K., Tanaka T., Noce T., Chuma S., Nakatsuji $N$. Tudor-related proteins TDRD1/MTR-1, TDRD6 and TDRD7/TRAP: domain composition, intracellular localization, and function in male germ cells in mice // Dev. Biol.-2007.-301, N 1.-P. 38-52.

9. Zukerberg R., Patrick N., Nikolic M., Humbert S., Wu C., Lanier L., Gertler F., Vidal M., Van Etten R., Tsai L. Cables links Cdk5 and $\mathrm{c}-\mathrm{Abl}$ and facilitates $\mathrm{Cdk} 5$ tyrosine phosphorylation, kinase upregulation, and neurite outgrowth // Neuron.-2000.-26, N 3.P. 633-646.

10. Kotaja N., Bhattacharyya S. N., Jaskiewicz L., Kimmins S., Parvinen $M$., Filipowicz $W$., Sassone-Corsi $P$. The chromatoid body of male germ cells: similarity with processing bodies and presence of Dicer and microRNA pathway components // Proc. Natl Acad. Sci. USA.-2006.-103, N 8.-P. 2647-2652. 
11. Yamochi T., Nishimoto I., Tsukasa Okuda T., Matsuoka M. ik31/Cables is associated with Trap and Pctaire2 // Biochem. Biophys. Res. Commun.-2001.-286, N 5.-P. 1045-1050.

12. Conte N., Delaval B., Ginestier C., Ferrand A., Isnardon D., Larroque C., Prigent C., Seraphin B., Jacquemier J., Birnbaum D. TACC1-chTOG-Aurora A protein complex in breast cancer // Oncogene.-2003.-22, N 50.-P. 8102-8116.

13. Richter $J$. Think globally, translate locally: What mitotic spindles and neuronal synapses have in common // Proc. Natl Acad. Sci. USA.-2001.-98, N 13.-P. 7069-7071.

14. Selenko P., Sprangers R., Stier G., Buhler D., Fischer U., Sattler $M$. SMN tudor domain structure and its interaction with the $\mathrm{Sm}$ proteins // Nat. Struct. Biol.-2001.-8, N 1.-P. 27-31.

15. Ponting $C$. $P$. Tudor domains in proteins that interact with RNA // Trends Biochem. Sci.-1997.-22, N 2.-P. 51-52.

16. Amikura R., Hanyu K., Kashikawa M., Kobayashi S. Tudor protein is essential for the localization of mitochondrial RNAs in polar granules of Drosophila embryos // Mech. Dev.-2001.-107, N 1-2.-P. 97-104.

17. Huyen Y., Zgheib O., Ditullio R. A. Jr., Gorgoulis V. G., Zacharatos P., Petty T. J., Sheston E. A., Mellert H. S., Stavridi E. S., Halazonetis T. D. Methylated lysine 79 of histone H3 targets 53BP1 to DNA double-strand breaks // Nature.-2004.-432, N 7015.-P. 406-411.

18. Jin J., Xie X., Chen C., ParkJ. G., Stark C., James D. A., Olhovsky M., Linding R., Mao Y., Pawson T. Eukaryotic protein domains as functional units of cellular evolution // Sci. Signal.2009.-2, N 98.-P. 1-19.

19. Cote J., Richard S. Tudor domains bind symmetrical dimethylated arginines // J. Biol. Chem.-2005.-280, N 31.-P. 2847628483.

20. Charier G., Couprie J., Alpha-Bazin B., Meyer V., Quemeneur E., Guerois R., Callebaut I., Gilquin B., Zinn-Justin S. The Tu- dor tandem of 53BP1: a new structural motif involved in DNA and RG-rich peptide binding // Structure.-2004.- 12, N 9.P. 1551-1562.

21. Thomson T., Lasko P. Tudor and its domains: germ cell formation from a Tudor perspective // Cell Res.-2005.-15, N 4.P. 281-291.

22. Callebaut I., Mornon J.-P. LOTUS, a new domain associated with small RNA pathways in the germline // Bioinformatics.2010.-26, N 9.-P. 1140-1144.

23. Lee C., Atanelov L., Modrek B., Xing Y. ASAP: the alternative splicing annotation project // Nucleic Acids Res.-2003.-31, N 1.-P. 101-105.

24. Skorokhod O., Nemazanyy I., Breus O., Filonenko V., Panasyuk $G$. Generation and characterization of monoclonal antibodies to TDRD7 protein // Hybridoma.-2008.-27, N 3.-P. 211-216.

25. Gudkova D. O., Panasyuk G. G., Nemazanyy I. O., Filonenko V. $V$. Novel antibodies against RCD-8 as a tool to study processing bodies // Biopolym. Cell.-2010.-26, N 6.-P. 512-516.

26. Zhyvoloup A., Nemazanyy I., Babich A., Panasyuk G., Pobigailo N., Vudmaska M., Naidenov V., Kukharenko O., Palchevskii S., Savinska L., Ovcharenko G., Verdier F., Valovka T., Fenton T., Rebholz H., Wang M. L., Shepherd P., Matsuka G., Filonenko $V$., Gout I. T. Molecular cloning of CoA Synthase. The missing link in CoA biosynthesis // J. Biol. Chem.-2002.-277, N 25.P. 22107-22110.

27. Wieckowski M. R., Giorgi C., Lebiedzinska M., Duszynski J., Pinton P. Isolation of mitochondria-associated membranes and mitochondria from animal tissues and cells // Nat. Protoc.2009.-4, N 11.-P. 1582-1590. 